\title{
Anthós
}

2014

\section{Veblen on National Economic Development}

Rebekkah Brainerd

Portland State University

Follow this and additional works at: https://pdxscholar.library.pdx.edu/anthos

Part of the European History Commons, and the Political History Commons Let us know how access to this document benefits you.

Recommended Citation

Brainerd, Rebekkah (2014) "Veblen on National Economic Development," Anthós: Vol. 6: Iss. 1, Article 5. https://doi.org/10.15760/anthos.2014.63

This open access Article is distributed under the terms of the Creative Commons Attribution-NonCommercialShareAlike 4.0 International License (CC BY-NC-SA 4.0). All documents in PDXScholar should meet accessibility standards. If we can make this document more accessible to you, contact our team. 


\title{
Veblen on National Economic Development
}

\author{
Rebekkah Brainerd
}

This inquiry seeks to establish that Thorstein Veblen introduces key ideas concerning national economic development in his book Imperial Germany and the Industrial Revolution. Using works by prominent scholars Alexander Gerschenkron and Gary Becker, this inquiry addresses the role of the state, human capital theory, and late industrialization theory. While specific ideas about the development of societies can be gleaned, ultimately it is about the individual factors of each society in how and why it develops as it does.

This inquiry seeks to establish that Thorstein Veblen introduced key ideas concerning national economic development in his book Imperial Germany and the Industrial Revolution (1915). Split into three main sections, this inquiry stresses the role of the state, human capital theory, and late industrialization. These three topics provide the foundation of Veblenian approaches to national economic development. Additionally, important thinkers Alexander Gerschenkron and Gary Becker are incorporated for further support and relevance in analyzing national economic development.

First, it is important to note that Veblen's analysis is particularly focused on the individual characteristics that make up different societies. Veblen (1915, Chapters 1-2) highlights the importance of the particulars that make up German civilization in describing how and why it developed as it did. Specifically, Veblen (1915, 8-9) describes Europe as having a "hybrid" make-up of peoples, which causes a natural adaptability due to cultural variety. This natural 
Anthós, Vol. VI, Issue 1

ability to adapt brings about ease in adopting new technology, a crucial and pivotal element in economic development.

Veblen (1915, 82-83) also affirms that societies adopting technologies from other societies do not have to embrace the corresponding institutions and habits of thought. This leads to the more efficient use of the borrowed technology, at least until institutions develop in response to the new borrowed technology. Two important ideas are found in these explanations: the importance of the individual characteristics of the state and the ability to borrow other technologies.

\section{The Role of the State}

As mentioned above, Veblen (1915, 67-68) emphasizes individual characteristics. For Germany, he particularly focuses on the culture of hierarchy and subordination as a source of strength. Specifically, Veblen (1915, 78-79) describes how emphasis on warfare creates a culture of obedience, as opposed to the individualism of Britain. In this way the Germanic people are attuned to group solidarity and following the direction of the "dynastic state." Through this, Veblen $(1915,77,157)$ asserts industry and the borrowing of technology as being state-directed. In this culture of obedience and vehement state focus, technological adoption and improvement could be completed in a short amount of time.

Yet Veblen (1915, 233-237) remains critical of this obedient culture and the patriotism of Germanic citizens, stating that it leads to an extreme focus on self-sufficiency and military strength. Contrasting Veblen's usual theory of wasteful or "conspicuous" consumption as described in Ken McCormick's book Veblen in Plain English (2006, 108-116), Veblen describes Germany as wasteful by channeling resources into warlike means. Veblen $(1915,238)$ sees this as inefficient, resulting in impoverishment for the common man and providing no real ability to ramp up military means if there is a true need. 
Alexander Gerschenkron's book Economic Backwardness in Historical Perspective: A Book of Essays (1962) is often considered in parallel with Veblenian theories of economic development. Gerschenkron's theory of “economic backwardness," or “underdeveloped states” in layman's terms, can be viewed in tandem to Veblenian theory. Gerschenkron $(1962,17)$ also writes about the close connection between economic development and military strength, emphasizing that development will often progress in fits and starts due to its dependence on military need. This places a harsh burden on workers in times of necessity, often resulting in a subsequent period of stagnated growth as the time of military necessity has pushed the common man beyond the limits of physical endurance.

Veblen (1915, 174) firmly believes that industry should be left unregulated, moving away from control by state authority for state ends. Veblen (1915, 171-173) remains suspicious of all protective measures in developing economics, believing that all state-controlled ends will have negative effects for the common man. However he does state that complete market freedom, at least in the case of Germany, "would have left the community dependent for a large and indispensable part of its current consumption on foreign countries... [and] the Empire would be relatively vulnerable in case of war...” While negative at face-value, this would also render the community more reluctant to go to war. In actuality, Germany enacted a "policy of reasonable restriction and pressure," a balance between free market and self-sufficient industry, in which the state directed vast resources towards political and warlike ends. Due to this being the State's focus, Veblen $(1915,209)$ purports that the common man has "absolutely nothing to gain in the material respect from the success of the Imperial State." Veblen $(1915,179)$ believes that, when studied closely, the success of the German people in the Imperial era was not achieved "by furtherance of the imperial state but in spite of it." Veblen does not have a clear modus operandi when it comes to the 
role of the state, but instead details the strengths and downfalls of each particular path in which a State could further economic development.

Paralleling Veblen's study of Germany, Gerschenkron $(1962,19)$ writes about economic development in respect to Russia. During this period of development when funds were greatly needed to finance large-scale industrialization, banks were highly reluctant to invest due to distrust and the perception of lack of integrity on the part of the public. Gerschenkron credits the response of the state here, citing the Russian government's success in using its taxation policies to direct incomes into investment. With the use of methods such as subsidies, tariffs, and extreme preference for domestic industry, Russia succeeded in increasing rates of growth and capital. Eventually, the perception of the banks towards the public grew favorable and led to the inflow of investment. Gerschenkron's study is an example of economic development using an approach of self-sufficiency.

Both Germany and Russia achieved industrialization on the backs of the common man, which Veblen and Gerschenkron critically point out. The common element in both of these states is the oppressive control and autocratic nature. Veblen (1915, 223-226) attests that as industrialization and the machine process fully permeate society, institutions of popular autonomy will come to change the culture of the society. In the case of Germany, Veblen says that industrialization is still much too young and immature, still in the process of adaptation, to have any real movement towards the ideals and institutions of the ideals of quasi-autonomy seen in Britain. Veblen $(1915,165)$ remarks that it took two hundred years for England to reach liberal policy, and not enough time has passed since the Prussian takeover of Germany for this change towards liberalism to occur. 


\section{Human Capital Theory}

The development of human capital theory is most commonly attributed to Gary Becker and his book Human Capital: a Theoretical and Empirical Analysis, with Special Reference to Education (1975). As can be seen from the title, Becker's focus is on the importance of education, which specifically emphasizes how an educated workforce increases productivity. While his analysis has much to do with mathematics and equations, it is the underlying theory and philosophy that can be related to Veblenian theory. Chapter 2 of Human Capital is important due to its emphasis on any and all education and training leading to improvements in productivity and higher wages. Becker $(1975,16,37)$ relates the difference between on-the-job and workerimplemented training and education, with a focus upon how and why a firm would give workers this training. Becker $(1975,40)$ also touches on about such things as improving emotional and physical health of workers.

Concepts of human capital theory within Imperial Germany can be drawn from Veblen's emphasis on how ideas are spread. Veblen (1915, 66-67) writes that throughout history, growth has not come about because of state action but because of education, close communication and the propagation of ideas. Continuing in this vein, Veblen (1915, 72-73) touches upon the importance of literacy and printing technology. Through these, he states, education and communication with other societies become available. However, Veblen sees a problem arising when he considers the low percentage of the population that is literate and has direct contact with this propagation of ideas. When addressing Germany, Veblen writes that the literate percentage of the population has actually been in contact with greater European ideas for years, but that the disconnect with the greater mass of Germany causes these ideas to only be applied in an academic setting. Through this example, Veblen highlights the importance of literacy and education in economic development. 
Anthós, Vol. VI, Issue 1

Veblen also mentions the illiterate class being more likely than the literate class to be engaged with the physical machine aspect of technology. Here a divide forms between the literate and illiterate class; they are out of touch with each other and thus the creation of a new order becomes very difficult. Veblen $(1915,184-185)$ further stresses German aptitude for the intelligence that the machine process requires, making it much easier to borrow. He mentions that all men have the ability of machine technology, but that it is a long process filled with much experimentation and this knowledge is often "opaque" in nature and slow to receive.

It is also relatable to mention Veblen's insistence on the importance of immaterial technology, or knowledge. He relates this specifically to the physical devastation that war causes, and the astonishment that most scholars have in how quickly societies can rebuild. Veblen attributes this to technological knowledge: even if physical technology is destroyed, people still possess the skills to rebuild and operate this technology. The opposite is not true; physical technology with no knowledge of how to use it makes the technology useless.

\section{Late Industrialization}

Veblen $(1915,241-242)$ and Gerschenkron $(1962,8)$ are known for their collective development of late industrialization theory. The core of late industrialization theory has to do with the borrowing of technology: societies that develop behind others can absorb and borrow technology without having to go through the tedious process of experimentation. With technological borrowing, the process of catching up to other, more technologically proficient societies, becomes much quicker and easier than the process of discovery and development. The goal is that this technology must be acquired.

Another important reason why developing countries catch up so quickly has to do with Veblen's $(1915,241)$ assertion that the developing country can borrow new technology without adopting the 
adjoining institutions. Germany was able to borrow industrial arts without having to adopt the institutions of waste that Veblen sees inherent in the more aged industrial culture of the British. Specifically, Veblen $(1915,264)$ stresses the important dichotomy between developed countries who put time and resources into wasteful consumption and "sportsmanship," while developing countries are using these resources towards productive means. In other words, the developing countries use time and resources to further growth that developed countries have tied up in wasteful habits.

Both authors mention several factors that have to be in place in order for an underdeveloped, or "backwards," economy to be able to develop. Both Gerschenkron (1962, 8, 17) and Veblen $(1915,76)$ accent the importance of political unification: no real industrialization can take place if Feudalism, particularism, or serfdom exists. Gerschenkron $(1962,9)$ mourns that, in contrast to popular theory, a productive labor force is extremely scarce in developing countries, which seems to tie into the need for investment in human capital. On an interesting note, Veblen $(1915,191)$ states that in Germany, labor supply was actually quite abundant.

Gerschenkron (1962, 14-16) also stresses the importance of banks in the economic development of backwards countries. He gives credit to the relationship between banks and the industrialization process for Germany's rapid growth. This is not to say that there were not downfalls: the direction of this growth was under bank control, causing German production to focus primarily upon particular profitable products. Gerschenkron further mentions that banks will often emphasize backwards characteristics by the encouragement of certain products over others - for example coal mining, steel production, and heavy chemical production. However, in Germany's case banks did encourage capital and industrialization, leading to German development. Gerschenkron $(1962,21)$ reports that with the achievement of German development, there is a process of liberation 
from direct bank control. However, the features and processes encouraged by the banks are still present, and while German-bank relations are on more equal grounds, a close relationship still exists.

Gerschenkron $(1962,24)$ includes one final important ingredient in development theory: faith. He purports that there must be faith and belief, for consumers and entrepreneurs alike, that the economy will succeed and a "golden age" lies just ahead. Gerschenkron believes that there needs to be an ideology of success to motivate and power the people and economy forward. This is strikingly similar to how McCormick (2006, 84-90) describes Veblen's theory of the business cycle, where Veblen describes the up and downs of the economy as dependent on the psychological state of mind of investors in the economy.

Gerschenkron (1962, 29-30) concludes his study by imploring states to understand that economic backwardness is not just the problem of the backwards state: it is the problem of everyone. He accentuates the importance of economic policies that take into consideration the peculiar nature of backwardness, and the danger that the military and autocracy can pose. Veblen (1915, 247-249) notes in Germany the rapid rise of military strength and resentful animosity, which in turn leads to further efforts of self-sufficiency. Here lies the danger: both to the common man who has to endure, and the high risk of warfare. History can attest to Germany's rise to development sparking two world wars.

\section{Conclusion and Discussion}

This inquiry sought to establish the key ideas of national economic development found within Thorstein Veblen's work Imperial Germany and the Industrial Revolution. In this, key ideas on the role of the state, human capital theory, and late industrialization theory forwarded by Gary Becker and Alexander Gerschenkron were found. 
It seems apt to return to the first idea mentioned by Veblen: the importance of the individual circumstances of each developing country. It was previously mentioned how Veblen focuses upon the individual characteristics of the peoples he was studying, considering the background and cultural effect that this would have upon adopting industrialization. When applying all of these theories to the developing countries of our day and age, it is crucial to note that these countries all belong to different continents. Different weather, history, race, and many other variables have created a completely different culture that will mix with the machine process in completely different ways. We can't expect them to develop, or act, the same as the societies of our past.

There are some firm truths to be gleaned from this inquiry - the necessity of education, political stability and unification, a strong labor class - but as Veblen points out, each State-controlled method of economic development has downfalls. It seems from this analysis that there is no perfect way for developing economies to become healthy states; each must live with the strengths and weaknesses of its own path. Yet everyone else has to live with these particular choices as well; this is where Gerschenkron's warnings becoming concerning. If war and animosity between peoples of closer heritage occurred in Europe, what does that say about the developing cultures in places like Africa and South America, whose cultures are an ocean away? Hopefully, we have learned from our past - yet this does not seem likely.

Perhaps this difference in cultural development with Veblen's machine process will not be as drastic as it seems. After all, Veblen's assertion, that the machine process causes habits of thought of autonomy and popular rule, may cause developing countries to eventually look much more familiar. Yet it is the time preceding this possible movement of liberalism that we must watch.

It will be very interesting to see what the world will look like, when and if world society as a whole has reached economic 
Anthós, Vol. VI, Issue 1

development. Will the mechanistic, quasi-autonomy culture of the machine process rule? Will the liberalist culture pervade, or will something entirely new develop as the machine process mixes with cultures across the world? To a certain degree, this has already begun. Alternations to the machine process stemming from cultural dissimilarity have already begun to arise, and we can expect to see further deviations as development continues.

\section{References}

Becker, G. (1975). Human Capital: A Theoretical and Empirical Analysis, With Special Reference to Education. New York: National Bureau of Economic Research.

Gerschenkron, A. (1962). Economic Backwardness in Historical Perspective: A Book of Essays. Cambridge, MA: Belknap Press.

McCormick, K. (2006). Veblen in Plain English. Youngstown, NY: Cambria Press.

Veblen, T. (1915). Imperial Germany and the Industrial Revolution. Akron, OH: Macmillian Publishers. 